Article

\title{
Sustainability of Investment Projects with Energy Efficiency and Non-Energy Efficiency Costs: Case Examples of Public Buildings
}

\author{
Mališa Đukić ${ }^{1, *(1)}$ and Margareta Zidar ${ }^{2}$ \\ 1 Belgrade Banking Academy, Faculty of Banking, Insurance and Finance, Union University, \\ 11000 Belgrade, Serbia \\ 2 Department for Energy Efficiency, Energy Institute Hrvoje Požar, HR-10000 Zagreb, Croatia; mzidar@eihp.hr \\ * Correspondence: djukicmalisa@hotmail.com
}

Citation: Đukić, M.; Zidar, M. Sustainability of Investment Projects with Energy Efficiency and Non-Energy Efficiency Costs: Case Examples of Public Buildings. Sustainability 2021, 13, 5837. https://doi.org/10.3390/su13115837

Academic Editors: Golam Kabir,

Sanjoy Kumar Paul, Syed Mithun Ali and Marc A. Rosen

Received: 30 March 2021

Accepted: 18 May 2021

Published: 22 May 2021

Publisher's Note: MDPI stays neutral with regard to jurisdictional claims in published maps and institutional affiliations.

\begin{abstract}
According to the European Commission Energy Union strategy from 2015, some of the main objectives are to improve energy efficiency, reduce dependence on energy imports, cut emissions, and drive jobs and growth. Achieving the objectives of the Energy Union requires significant financing, particularly for investments in energy efficiency. Serbia and Croatia included the objectives of the Energy Union in their national strategies and have implemented various investment projects in this area. This paper focuses on the sustainability of energy efficiency projects for public buildings which include not only energy efficiency investment cost but also non-energy efficiency investments. By applying the European Commission methodology for cost-benefit analysis, we assessed the sustainability of several projects in Serbia and Croatia. The sustainability assessment is done by quantifying energy savings, greenhouse gas emission reductions and the social and economic benefits that are related to non-energy efficiency project components. The values of economic performance indicators imply that society would be better off with projects that would contribute to achieving not only the targets set in national energy strategies but also to creating broader social benefits.
\end{abstract}

Keywords: investment projects; financial analysis; economic analysis; energy efficiency; public buildings; sustainability

\section{Introduction}

The buildings sector in the EU contributes to approximately $36 \%$ of $\mathrm{CO}_{2}$ emissions and $40 \%$ of final energy consumption, while $75 \%$ of the building stock is energy inefficient and $35 \%$ of buildings are over 50 years old [1]. Due to the Energy Efficiency Directive (2012/27/EU and 2018/2002) (EED), the annual rate of refurbishment should amount to $3 \%$ of the total surface area of buildings occupied by the central government [2]. The Directive on Energy Performance of Buildings (2010/31/EU and 2018/844) (EPBD) requires decarbonizing the national building stocks by 2050 by establishing national long-term renovation strategies [3]. In addition to these energy efficiency related directives, the Directive 2018/2001 on the Promotion of the use of Energy from Renewable Sources (REDII) calls for more renewable-based heating and cooling in buildings [4]. Current annual renovation rates of the building stock across Member States ranges from $0.4 \%$ to $1.2 \%$, and to reach the targeted 3\%, many barriers to renovation need to be overcome [5].

In this paper, we focus on analyzing the sustainability of investing in several public buildings in Croatia and Serbia. The objective of the study is to assess the technical, financial, and economic feasibility of investment projects in three public buildings by calculating corresponding performance indicators. This paper addresses the following questions: What is the energy consumption in each case? What are the technical options and what are their implications on the energy performance of buildings? Do the options contribute to the decarbonization of the building stock? What are the investment, operation 
and maintenance costs and energy savings per every option? Which option offers the most cost-effectiveness? Is the proposed project financially viable? What are the energy efficiency and non-energy efficiency benefits in every case? Do the energy efficiency benefits justify the costs? If not, how can the economic viability of the cases presented in this paper be assessed?

In Croatia, from 2014 until 2020, the energy refurbishment of buildings was co-financed by the European Structural and Investment funds with $60 \%$ for energy efficiency measures and $85 \%$ for design documentation, energy audit and energy certificate costs [6]. To qualify for the co-financing, at least $50 \%$ of heating energy savings was required and usually this was achieved by the thermal insulation of the building envelope and the installation of energy efficient windows. The market was highly motivated to use grants for financing the energy refurbishment costs. There were 758 projects of public buildings and the total co-financing amount was EUR 211.81 million. In residential buildings, i.e., multiapartment buildings and family houses, which included a total of 16,000 households, there were 584 projects and the total co-financing amount was EUR 100 million [7]. Even though this is a relatively high number of projects and financial resources invested, an annual refurbishment rate of $0.7 \%$ of the total building stock was achieved and 1.35 million $\mathrm{m}^{2}$ of the building surface area were refurbished. According to the recently published National building stock refurbishment strategy, a gradual increase in the annual refurbishment rate is targeted, starting from 1\% in 2021 and reaching 4\% in 2050, and expecting to refurbish a total of 104 million $\mathrm{m}^{2}$ and to achieve $2260.9 \mathrm{ktCO}_{2}$ savings [8]. Decarbonization of the building stock will include additional energy efficiency measures, such as modernizing the building systems, using on-site renewable energy, and developing neighborhood renovation projects instead of single building projects. In Serbia, according to the Energy sector development strategy until 2025, the energy refurbishment of buildings has been set out as a priority activity.

To assess the sustainability of the investment projects in several public buildings in Serbia and Croatia, we took into consideration both energy efficiency and non-energy efficiency costs and benefits. Economic performance indicators imply that energy efficiency benefits may not be sufficient to justify the project costs. The inclusion of non-energy efficiency benefits improves the results of the economic analysis, making the projects desirable from a socioeconomic perspective.

The paper is organized as follows. Section 2 provides a literature review. Methods on energy audits, certificates of buildings and the cost-benefit analyses of investment projects are introduced in Section 3. Case examples of a building in Croatia and two buildings in Serbia are elaborated in Section 4. Results and discussion on energy cost savings, option analysis and cost-benefit analyses are presented in Section 5. Finally, conclusions are presented in Section 6.

\section{Literature Review}

Improving energy efficiency has been a way to increase the productivity and sustainability of society, primarily through the delivery of energy savings. The impact of energy efficiency measures can be an important contributor to economic growth and social development [9]. To investigate the complex and controversial relationship between energy consumption and GDP, a study concluded that there is mixed evidence on the direction of causality between energy consumption and GDP [10]. Job creation is an important socioeconomic effect associated with the development of energy efficiency technologies. The approaches to estimate job creation effects of the renewable energy and energy efficiency sectors, as well as the existing estimations of job creation figures by technology and capacity, were summarized in the literature [11,12]. Kerr et al. considered how different benefits have been used within the overall rationale for energy efficient retrofit policies in different contexts [13]. The identification of multiple benefits may not imply multiplied policy support, and instead it is more likely that different rationales will have relevance at different times, for different audiences [13]. 
Bleyl et al. analyzed the economic and financial implications for renovating an office building to the "Passive House" standard and concluded that the Life Cycle Cost \& Benefit Analysis cash flow model can be used not only for deep energy retrofit business case analysis, project structuring, and financial engineering, but also for policy design [14]. Gelatioto et al. simulated a public historic building and some permitted retrofit actions were applied to analyze the effectiveness of national measures in four different climatic zones [15]. Energy efficiency retrofitting of existing buildings is a key program for improving building energy efficiency in northern regions of China. A methodological framework to conduct an economic cost-benefit analysis (CBA) for energy efficiency retrofit projects was applied and the research found that the retrofitting of existing buildings generally lacks attractiveness to investors from an economic perspective [16]. Energy saving retrofits of residential and public buildings positively contributed to economic growth, employment, and protection of the environment in a post-transition country [17].

Novikova et al. analyzed the costs and benefits of the different thermal efficiency retrofits as well as the impact of user behavior, implying that energy usage in the public building sector could increase and mitigate savings resulting from energy-saving measures, making saved energy costs invisible [18]. By reducing energy consumption, other benefits can be achieved such as reduced government subsidies and improved health due to less air pollution and a better indoor climate [19]. Filippidou and Jimenez Navaro [1] have used CBA to identify the cost effective and cost optimal solutions for current and future EU building stock. Both energy efficiency and sustainable heating and cooling should be considered when planning the decarbonization of the building sector, thus avoiding lock-in effects in terms of investments in less than cost-optimal energy efficiency renovations. Costoptimal solutions require moderate thermal insulation in southern Europe, and efficient heating and cooling technologies should be prioritized. On the other hand, in central Europe, deep energy efficiency improvements are cost-optimal and should be combined with efficient heating and cooling technologies.

The renovation of large scale buildings is still a difficult task to be accomplished. The most prevalent reasons for this are, among others, large investments and lack of awareness of the potential benefits and of the skills required [20,21]. Papers published so far evaluate the co-benefits (or multiple benefits) of a portfolio of energy efficiency projects by quantifying the effects of such projects on selected macroeconomic variables [9-11,17-19,22]. In our paper, we try to contribute to the literature by estimating the economic performance of energy efficiency investments in public buildings on a case-by-case basis.

\section{Methods}

The European Commission methodology is applied to assess the technical, financial and economic feasibility of proposed investments in three public buildings [23]. Figure 1 presents the appraisal steps.

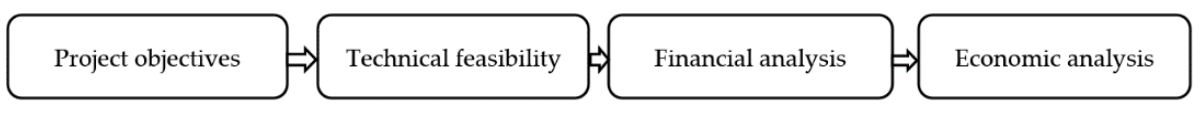

Figure 1. Project appraisal methodology steps (Source: Adapted from Sartori et al. [23]).

Project objectives are elaborated in Section 4. The methodology on technical feasibility with option analysis as well as the financial and economic analysis is presented in Sections 3.1 and 3.2, respectively.

\subsection{Energy Audits and Certificates of Buildings}

Energy savings in buildings are determined in an energy audit. There are several standards for conducting energy audits, and the most used ones are ISO 50002:2014 and EN 16247-1:2012, which promote similar basic steps targeted to identify current energy performance of a building and building systems and the energy performance improvement 
measures. The energy audit process has two implementation steps, (1) Data collection \& Site Visit, and (2) Analysis \& Reporting.

The data collection includes discussion with the building owner and user to define the energy audit purpose and scope, to acquire data on the building and the energy bills. Next, a site visit is undertaken to record findings on the current condition of the building's elements and systems, and to identify opportunities for energy savings [24].

Savings are achieved by considering various energy efficiency measures that improve energy performance of building components and systems. Baseline energy consumption, costs and $\mathrm{CO}_{2}$ emissions are determined from the energy bills. Feasibility of energy efficiency measures is determined by technoeconomic analysis of the investment costs and the saving potential presented in energy, $\mathrm{CO}_{2}$ emissions and costs $\left(\mathrm{kWh} / \mathrm{y}, \mathrm{tCO}_{2} / \mathrm{y}, \mathrm{EUR} / \mathrm{y}\right.$, respectively). Additional financial indicators as simple payback period (SPB), discounted payback period (DPB), internal rate of return (IRR) and investment net present value (NPV) are also prepared to describe the effectiveness of the energy efficiency measures. All findings on the current energy performance, energy efficiency measures and the improved energy performance of a building are described in a report, which is presented to the building owner and user to make the decision on the implementation of energy efficiency measures.

The EPBD has defined a general framework for the calculation of the energy performance of buildings where the heat energy demands for heating and cooling, along with energy efficiency levels of the building systems, are assessed. The energy performance certificate is a document where the unique energy performance indicator is presented, grading the building's energy performance in energy classes, from $\mathrm{A}+$ as the most efficient level, to $\mathrm{G}$ as the lowest efficiency level.

For existing buildings, which are usually graded in low energy efficiency classes from $D$ to $G$, there is a high energy saving potential. Deep energy refurbishment measures, such as thermal insulation of the building envelope and on-site renewable energy-based technologies, achieve energy savings of up to $80 \%$ and the highest energy classes. Major refurbishment is usually focused on thermal insulation measures and saving up to $50 \%$ more energy and energy classes $B$ or $C$ are reached. Minor refurbishment includes improvements of the existing building systems while savings can range up to $30 \%$ and the energy class usually improves one level up.

In the option analysis, cost effectiveness rather than cost efficiency should be targeted. Implementing lower levels of energy performance may lead to locking-in energy consumption to unsustainable patterns due to long-term lack of proper maintenance, which remain unchanged for several decades until the next renovation cycle [25]. As future renovation rates are expected to remain close to the current level, it is highly important to make sure that the best available energy efficiency measures are included [26]. In our paper, the selection of the preferred options is based on cost effectiveness, which allows for high energy savings.

\subsection{CBA Methodology}

CBA is defined as an activity that enables calculating and comparing costs and benefits of an investment project. The impact of financial, economic, social and other factors should be considered in order to assess the financial and economic viability of projects [27]. When the value of benefits exceeds the costs incurred, the project is feasible. When an activity undertaken by an individual or a company affects other individuals or companies who do not pay for that activity or are not paid, the effect can be either positive or negative; therefore, there are positive or negative externalities [28]. Sáez and Requena emphasize that CBA includes our own intergenerational ethics, expressing what our present generation is willing to pass on to future generations and not the future generations' preferences [29]. They propose the use of the common Social Discount Rate for market goods and a lower discount rate (environmental discount rate) for non-market goods in the same CBA exercise as a way to include a certain level of intergenerational equity [29]. 
In this paper, $\mathrm{CBA}$ is performed in line with the European Commission Guide to cost-benefit analysis of investment projects, hereafter the EC CBA Guide [23]. CBA includes financial analysis and economic analysis. The financial analysis is made on behalf of the owner of the infrastructure. The methodology used is the Discounted Cash Flow (DCF) method. Only cash inflows and outflows are considered in the analysis, i.e., depreciation, reserves, price and technical contingencies and other accounting items which do not correspond to actual flows are disregarded. The reference period is 20 years. The analysis is carried out in constant (real) prices, net of value added tax (VAT), both on costs and revenues.

The incremental approach is applied, comparing the with-project scenario and the without-project scenario. The with-project scenario assumes the implementation of the proposed investment and operations within the reference period. The without-project scenario is a counterfactual scenario and indicates what would happen in the absence of the project.

It is assumed that the energy price will be increased according the electricity price forecasts in the South East Europe Electricity Road Map Country Report [30]. Projected electricity price growth rates are applied to estimated electricity cost. Fuel scenarios developed for the Ten-Year Network Development Plan (TYNDP) 2018 from the European Network of Transmission System Operators (ENTSOs) were considered with regards to gas price [31]. Projected gas price growth rates are applied to estimated heating cost.

The economic analysis is made on behalf of the whole society and appraises the project's contribution to the economic welfare of the region or a country. Investment projects often have impacts that have no direct market values such as the impacts on the environment. These effects can be monetized through different valuation techniques. The key objective of the economic analysis is to prove that the present value of the project's economic benefits exceeds the present value of its economic costs, which means that the project has a positive net contribution to society. This is expressed as a positive Economic Net Present Value of the net cash flow, a Benefit/Cost (B/C) ratio higher than 1,0 or a project's economic rate of return (ERR) exceeding the social discount rate. The economic analysis is based on an incremental approach, comparing economic cost and benefits of the project. Constant prices are applied and a social discount rate of $5 \%$ is used. As no particular salary distortions are foreseen, the conversion factor of 1 is used. The following five steps are applied: (1) conversion from market to accounting prices, (2) monetization of non-market impacts, (3) inclusion of additional indirect effects, if relevant, and (4) discounting of the estimated costs and benefits and calculation of the economic performance indicators [23].

In this paper, we assessed energy efficiency and non-energy efficiency benefits. Energy efficiency benefits included O\&M cost savings, avoided $\mathrm{CO}_{2}$ emissions, avoided cost of airborne pollutants and enhanced security of supply. The non-energy efficiency benefits are specific for every building and may comprise education-related benefits, avoided healthcare costs and avoided cost of child care, if applicable.

The recommended values of European Commission (EC) for the shadow price of $\mathrm{CO}_{2}$ are used in the economic analysis and are available in the European Commission Directorate-General for Climate Action paper on Climate Change and Major Projects [32]. Changes in the emissions of airborne pollutants are also monetized (PM, NOx, SOx) with unit damage values from the NEEDS study [33]. If the with-project temperature will be different from the current temperature, the project would create incremental comfort benefits. The project is expected to generate security-of-supply benefits at a shadow price used by the European Investment Bank (EIB) and the EC for power generated from a combined cycle gas turbine (CCGT) [23].

When applicable, education related benefits are assigned. Such benefits would result from improved quality of health care services and an increase in the number of survivors. Value of a Statistical Life (VSL) and income elasticities are elaborated by Viscusi and Masterman [34]. 


\section{Case Examples of Public Buildings}

\subsection{Building 1-Hospital}

Building 1 is a clinical hospital built in 1988 and is located in Zagreb, Croatia. The building is graded in energy class $\mathrm{F}>220 \%$. Electricity accounts for $48 \%$ of total operational costs, natural gas for $19 \%$ and water for $33 \%$. Although the investment maintenance has been implemented over the years, the building systems have reached the end of life and many damages can be observed on the building envelope. Leakage of the flat roofs is occurring continuously due to the large roof surface area, damaged stormwater outlets and damaged skylights. Building systems lack all functionalities that would enable stable and efficient supply of energy, as part of the damaged equipment like heat recovery and humidification systems were not replaced due to high investment costs. The window opening mechanisms, window sealing and prefabricated façade panels with thermal insulation layers are damaged, causing increased heat losses. The water supply and hydrant network lack proper system pressure due to frequent pipe bursting while all water fixtures are damaged with continuous leakage. Investment not only in energy efficiency improvement but also in other major building properties is needed, but the respective refurbishment program finds only energy efficiency measures and water saving measures eligible for co-financing.

Energy efficiency measures proposed for this building include reducing heat demand by improving the thermal insulation of the external envelope, the full replacement of the centralized air-conditioning and mechanical ventilation systems and the replacement of steam boilers with hot water boilers. A new lighting system and automation and control for all building systems with integration in the central management and surveillance system are suggested. In addition, the revitalization of laundry and kitchen facilities, refurbishment of the external hydrant network, introducing new efficient water saving fixtures, refurbishment of the entire indoor supply pipeline, photovoltaic system and solar thermal collectors are included. Option analysis is performed for this building indicating various energy efficiency levels of the energy efficiency measures proposed. Option A presents the minimum improvements of the building envelope and building systems. Option B aims at achieving the overall highest energy efficiency level. In addition to the improvements of option $\mathrm{B}$, option $\mathrm{C}$ includes a higher building envelope performance. The building will be graded in energy class $C<100 \%$ following the implementation of the proposed investment.

\subsection{Building 2-Emergency Health Care Center}

Building 2 was built in 1975 as a medical facility in Belgrade, Serbia. The building is undergoing significant surface expansion to improve substandard working conditions and to introduce new medical services. The building is graded in energy class $\mathrm{E}>150 \%$. Electricity accounts for $30 \%$ of total operational costs, heat energy for $67 \%$ and water for $3 \%$. The overall poor conditions due to lack of adequate maintenance on all installations and the building structure can be observed, such as leakage of the flat roofs and façade damages. The existing building systems have substandard energy performance levels, and additional power capacity, proper cabling and illumination level of the lighting system, replacement of damaged sanitary furniture, improvement of indoor air quality and indoor comfort both in summer and winter period are required.

The energy efficiency measures proposed for this building include the reduction of heat demand by improving the thermal insulation of the external envelope. The supply of heat from the existing district heating system will remain, but the heat distribution and transfer system will be completely replaced. Moreover, solar thermal collectors, a new centralized cooling system, a ventilation system with heat recovery for high priority areas and building energy management system will be introduced. The sustainability measures include the reinforcement of the existing loadbearing structure, fire protection systems and installations, new water and sewage installations, the complete replacement of the electrical installations, as well as back-up energy generators and reliable and high- 
capacity telecommunication installations. Auxiliary services (kitchen, restaurant, laundry, car wash), accessibility infrastructure for disabled persons, a video surveillance system and traffic and landscape infrastructure are provided. Option A includes the minimum energy efficiency improvement of all building elements and systems and is in line with national energy efficiency requirements, while option B introduces solar thermal system additionally. Option $C$ incorporates the mechanical ventilation systems with heat recovery in high priority areas. The building will be graded in energy class $\mathrm{B}<50 \%$ in the withproject scenario. CBA is performed for the preferred option.

\subsection{Building 3-Kindergarten Complex}

Building 3 is a kindergarten complex with administration offices and a kitchen facility in Belgrade, Serbia. The building was built in 1975 and is graded in energy class E $>200 \%$. Electricity accounts for $37 \%$ of total operational costs, heat energy for $58 \%$ and water for $5 \%$. The building was thermally insulated in 2009 but with the minimum performance of the façade and windows. The indoor thermal comfort in heating season is low due to insufficient heating capacity of the central light heating oil boiler plant. Individual electric heating units are used for the additional heating of rooms. The power capacity is not sufficient to cover all electric equipment installed.

Energy efficiency measures proposed for this building include reducing heat demand by improving the thermal insulation of the external envelope. Modernization of building systems introduces heat pumps for heating and cooling, a mechanical ventilation system with heat recovery, solar thermal collectors, a new lighting system and a building energy management system. Option A includes the minimum energy efficiency improvement of all building elements and systems and is in line with national energy efficiency requirements. Option B introduces the solar thermal system and heat pump, while option C incorporates the mechanical ventilation and heat recovery. The building will be graded in energy class $B$ $<50 \%$ following the implementation of the proposed investment. The with-project scenario of CBA is based on the preferred option.

\section{Results and Discussion}

\subsection{Building 1-Hospital}

The investment cost in various options is from 432 to $500 \mathrm{EUR} / \mathrm{m}^{2}$ while the operational cost savings range from 21 up to $39 \mathrm{EUR} / \mathrm{m}^{2}$ (Table 1). The simple payback period is from 10 to 21 years. Option B is the most cost-effective one with the highest operational cost saving, and with an annual electricity saving of $24 \%$, heat saving of $67 \%$, water saving of $42 \%$ and $\mathrm{CO}_{2}$ saving of $57 \%$. Renovation costs in hospitals in Albania for building envelopes and heating systems were assessed in the literature [18]. Due to the difference in investment objectives, their findings are not comparable to the results of option analysis.

For Option B, the NPV amounts EUR $-406,840$ and the IRR is $3.73 \%$. With $40 \%$ cofinancing, the NPV is EUR 8.8 million and the IRR is $12.53 \%$. The results suggest that an energy efficient renovation investment, if not supported by government grants, may not be financially viable. This is in line with previous findings that government support could significantly improve the financial viability for investors $[17,19]$. 
Table 1. Investment cost and savings for various options for Building 1.

\begin{tabular}{cccc}
\hline Building $\mathbf{1}$ & Option A & Option B & Option C \\
\hline Investment [EUR $\left./ \mathrm{m}^{2}\right]$ & 432 & 480 & 500 \\
Heat saving $\left[\mathrm{kWh} / \mathrm{m}^{2}\right]$ & 325 & 590 & 598 \\
Electricity saving $\left[\mathrm{kWh} / \mathrm{m}^{2}\right]$ & 29 & 37 & 40 \\
Water saving $\left[\mathrm{m}^{3} / \mathrm{m}^{2}\right]$ & 4 & 4 & 4 \\
Energy class & $\mathrm{D}$ & $\mathrm{C}$ & $\mathrm{C}$ \\
$\mathrm{CO}_{2}$ saving [tCO $\left./ \mathrm{m}^{2}\right]$ & 107 & 145 & 146 \\
Operational cost saving [EUR $\left./ \mathrm{m}^{2}\right]$ & 21 & 46 & 39 \\
Simple payback period [years] & 21 & 10 & 13 \\
\hline
\end{tabular}
Source: Authors' calculations.

\subsection{Building 2-Emergency Health Care Center}

The investment cost ranges from 67 up to $94 \mathrm{EUR} / \mathrm{m}^{2}$ while the operational cost saving varies from 5 up to $14 \mathrm{EUR} / \mathrm{m}^{2}$ (Table 2). Total energy savings vary from $41 \%$ up to $49 \%$. Option B has the shortest simple payback period, however, option C is the most cost-effective as it provides higher indoor comfort.

Table 2. Investment cost and savings for various options for Building 2.

\begin{tabular}{cccc}
\hline Building 2 & Option A & Option B & Option C \\
\hline Investment $\left[\mathrm{EUR} / \mathrm{m}^{2}\right]$ & 149 & 157 & 192 \\
Heat saving $\left[\mathrm{kWh} / \mathrm{m}^{2}\right]$ & 99 & 131 & 147 \\
Electricity saving $\left[\mathrm{kWh} / \mathrm{m}^{2}\right]$ & 35 & 36 & 24 \\
Energy class & $\mathrm{C}$ & $\mathrm{B}$ & $\mathrm{B}$ \\
$\mathrm{CO}_{2}$ saving $\left[\mathrm{tCO} / \mathrm{m}^{2}\right]$ & 0.011 & 0.017 & 0.015 \\
Operational cost saving $\left[\mathrm{EUR} / \mathrm{m}^{2}\right]$ & 6 & 8 & 9 \\
Simple payback period [years] & 24 & 19 & 23 \\
\hline
\end{tabular}

Source: Authors' calculations.

The investment cost is estimated to be EUR 7.3 million and includes energy efficiency (EE) components and non-EE components with $54 \%$ and $46 \%$ share, respectively (Table 3 ). EE components comprise architecture, thermotechnical and electrical items, while non-EE components contain architectural, structural, sanitary, telecommunication, fire detection and alarm system, vertical transport, demolition works, smoke extraction, sprinkler system and landscaping items.

Table 3. Investment cost of Building 2.

\begin{tabular}{ccc}
\hline Item & EUR & $\%$ \\
\hline EE components & $3,950,000$ & $54 \%$ \\
Non-EE components & $3,330,000$ & $46 \%$ \\
Total investment cost & $7,280,000$ & $100 \%$ \\
\hline
\end{tabular}

Source: Authors' calculations.

Operation and maintenance $(\mathrm{O} \& \mathrm{M})$ costs include electricity, heating and maintenance costs of both EE and non-EE components (Table 4). Due to the energy cost savings that would result from the project implementation, the incremental operation and maintenance costs are negative from the first year of operations in the amount of EUR - 5.804. The energy costs are adjusted to the forecasted changes of energy prices as elaborated in the methodology section of the paper. 
Table 4. Incremental O\&M cost in the first year of project operations.

\begin{tabular}{cc}
\hline Item & EUR \\
\hline Electricity cost & -29.647 \\
Heating cost & -16.077 \\
Maintenance cost & 39.920 \\
Total incremental O\&M costs & -5.804 \\
\hline
\end{tabular}
Source: Authors' calculations.

The economic costs include the investment cost, replacement cost and residual value (Table 5). As the weighted average life time of investment cost items is equal to the reference period of 20 years, the replacement costs and residual value are set to EUR 0 . Since the project generates energy savings, incremental O\&M costs are presented as economic benefits. The net present value of economic costs is EUR 6.9 million.

Table 5. CBA results for Emergency Health Center.

\begin{tabular}{ccc}
\hline Item & Net Present Value & $\%$ \\
\hline Investment cost & $6,933,333$ & $100.0 \%$ \\
Replacement cost & 0 & $0.0 \%$ \\
Residual value & 0 & $0.0 \%$ \\
Total economic costs & $6,933,333$ & $100.0 \%$ \\
Avoided CO COmissions $_{\text {O\&M cost savings }}$ & 56,950 & $0.7 \%$ \\
Avoided cost of airborne pollutants & 157,678 & $2.0 \%$ \\
Enhanced security of supply & 85,441 & $1.1 \%$ \\
Education benefits & 13,936 & $0.2 \%$ \\
Total economic benefits & $7,674,430$ & $96.1 \%$ \\
Economic net present value & $7,988,436$ & $100.0 \%$ \\
\hline
\end{tabular}

Source: Authors' calculations.

The O\&M cost savings are a major energy efficiency related benefit with the net present value of EUR $157 \mathrm{k}$ and a $2.0 \%$ share of total benefits. The avoided cost of airborne pollutants follows in importance with a $1.1 \%$ share (EUR $85 \mathrm{k}$ ). The avoided $\mathrm{CO}_{2}$ emissions and the enhanced security of supply account for $0.9 \%$ of the total. The project implementation would not generate incremental revenues. Benefits from education with a net present value of EUR 7.98 million are considered as a non-EE benefit and are a result of improved quality of health care services. The economic net present value is EUR 1.0 million while the benefit/cost ratio is 1.15 . Such economic performance indicators imply that the society would be better off with the project. The energy efficiency benefits are not sufficient to justify the EE investment cost. The inclusion of non-EE costs and benefits in the analysis provides the basis for the comprehensive assessment of the project's feasibility. The assessment of co-benefits or multiple project benefits of various projects, which include the impact on GDP, employment, labor income, rental income and building sales price, is presented in the literature $[11,14,16-18]$. Since these benefits are not included or applicable to the cases in this paper, the results of the CBA are not comparable to the indicators presented in the literature.

A sensitivity analysis was then performed to identify the effect of the choice of a discount rate on the weighing of costs and benefits. If the social discount rate would increase, the net present value would decrease as the costs come up-front and benefits come later. A relevant element of the sensitivity analysis is a value that a variable (social discount rate) would take in order for the net present value of the project to become zero or negative.

If a rate of $7 \%$ is used, the benefit/cost ratio is $0.99 \%$ and the net present value is negative (Table 6). Such results would suggest that the project is not economically viable only due to the increase in the social discount rate from $5 \%$ to $7 \%$. In the case of the 
Emergency Health Center, an additional increase in the discount rate ( $7 \%$ or higher) would further deteriorate the results of the cost-benefit analysis.

Table 6. Results of economic analysis under different social discount rates for the Emergency Health`Center.

\begin{tabular}{ccc}
\hline Social Discount Rate & $\mathbf{5 \%}$ & $\mathbf{7 \%}$ \\
\hline Benefit/cost ratio & 1.15 & 0.99 \\
Economic net present value & EUR 1.0 million & EUR $-72,013$ \\
\hline
\end{tabular}

Source: Authors' calculations.

\subsection{Building 3-Kindergarten Complex}

The investment cost in various options is from 203 up to $494 \mathrm{EUR} / \mathrm{m}^{2}$ while the operational cost savings is from 19 up to $26 \mathrm{EUR} / \mathrm{m}^{2}$ (Table 7). The total energy savings vary from $50 \%$ to $80 \%$ in different options. Option $C$ achieves the highest savings of operational costs and $\mathrm{CO}_{2}$ emissions and is the selected (preferred) option. The renovation costs of the building envelope and heating systems in kindergartens in Albania were assessed in the literature [18]. Since the investment objectives are not the same, their findings are not comparable to the results of option analysis.

Table 7. Investment cost and savings for various options for Building 3.

\begin{tabular}{cccc}
\hline Building 3 & Option A & Option B & Option C \\
\hline Investment $\left[\mathrm{EUR} / \mathrm{m}^{2}\right]$ & 203 & 321 & 494 \\
Heat saving $\left[\mathrm{kWh} / \mathrm{m}^{2}\right]$ & 114 & 190 & 302 \\
Electricity saving $\left[\mathrm{kWh} / \mathrm{m}^{2}\right]$ & 19 & 1.76 & 15 \\
Energy class & $\mathrm{C}$ & $\mathrm{B}$ & $\mathrm{B}$ \\
$\mathrm{CO}_{2}$ saving $\left[\mathrm{tCO} / \mathrm{m}^{2}\right]$ & 0.06 & 58 & 92 \\
Operational cost saving $\left[\mathrm{EUR} / \mathrm{m}^{2}\right]$ & 19 & 21 & 26 \\
Simple payback period [years] & 10 & 15 & 13 \\
\hline
\end{tabular}

Source: Authors' calculations.

The project investment cost is estimated to be EUR 2.0 million and includes energy efficiency (EE) components and non-EE components with an $82 \%$ and $18 \%$ share, respectively (Table 8). The EE components comprise the building envelope, mechanical systems, solar thermal system, lighting system, architecture and mechanical items, while non-EE components include electrical, firefighting, interior works, structural, demolition works and sanitary items.

Table 8. Investment cost of kindergarten complex.

\begin{tabular}{ccc}
\hline Item & EUR & $\%$ \\
\hline EE components & $1,650,000$ & $82 \%$ \\
Non-EE components & 370,000 & $18 \%$ \\
Total investment cost & $2,020,000$ & $100 \%$ \\
\hline
\end{tabular}

Source: Authors' calculations.

The project generates significant energy savings with the incremental operation and maintenance costs of EUR $-45 \mathrm{k}$ in the first year of operations (Table 9). The savings are attributed to the heating cost reduction. Energy costs are adjusted over the reference period as stated in the methodology section of the paper. 
Table 9. Incremental O\&M cost in the first year of project operations.

\begin{tabular}{cc}
\hline Item & EUR \\
\hline Electricity cost & 1768 \\
Heating cost & $-66,481$ \\
Maintenance cost & 19,652 \\
Total incremental O\&M cost & $-45,061$ \\
\hline
\end{tabular}
Source: Authors' calculations.

The net present value of economic costs is EUR 1.9 million (Table 10). Replacement costs and residual value are set to EUR 0 as the average life time of cost components correspond to the reference period.

Table 10. CBA results for the kindergarten complex.

\begin{tabular}{ccc}
\hline Item & Net Present Value & $\%$ \\
\hline Investment cost & $1,942,308$ & $100.0 \%$ \\
Replacement cost & 0 & $0.0 \%$ \\
Residual value & 0 & $0.0 \%$ \\
Total economic costs & $1,942,308$ & $100.0 \%$ \\
Comfort benefit & $1,604,852$ & $57.1 \%$ \\
Avoided CO $\mathrm{CO}_{2}$ emissions & 292,240 & $10.4 \%$ \\
Avoided cost of airborne pollutants & 246,206 & $8.8 \%$ \\
Enhanced security of supply & 7182 & $0.3 \%$ \\
Avoided cost of child care & 544,230 & $19.4 \%$ \\
Avoided health care costs of influenza & 116,529 & $4.1 \%$ \\
Total economic benefits & $2,811,240$ & $100.0 \%$ \\
Economic net present value & 868,932 & \\
\hline
\end{tabular}

Source: Authors' calculations.

The with-the-project temperature will be higher by 2 degrees Celsius than the current temperature, resulting in a comfort benefit. This benefit is monetized on the basis of the hypothetical additional energy savings associated with a hypothetical higher energy consumption in the without-project scenario that would have been needed to reach the temperature of the with-project scenario [23]. The comfort benefit is a major energy efficiency and project benefit, with the net present value of EUR 1.6 million and a 57.1\% share of total benefits. The avoided $\mathrm{CO}_{2}$ emissions and cost of airborne pollutants follow in importance, with EUR $292 \mathrm{k}$ and EUR 246 k, respectively. The enhanced security of supply is estimated to EUR $7.2 \mathrm{k}$. Due to the improved internal air quality and temperature, a conservative decrease in absence rate by $1 \%$ is applied [35]. The benefit is quantified on the basis of avoided costs of private child care during illness and the associated health costs of EUR $544 \mathrm{k}$ and EUR $116 \mathrm{k}$, respectively. The economic net present value is EUR 0.87 million while the benefit/cost ratio is 1.45 . The benefits on society justify the opportunity cost of the investment. In this case, EE benefits would be sufficient to justify the EE investment cost. The inclusion of non-EE costs and benefits enables the assessment of the project's impact on society as a whole. The results are not evaluated against the results in previous studies $[11,14,16-18]$ since the structure of the project benefits is not comparable.

A sensitivity analysis was performed to quantify the effect of increasing the social discount rate. A relevant element of the sensitivity analysis is a value that a variable (social discount rate) would take in order for the net present value of the project to become zero or negative.

If a rate of $8 \%$ is used, the benefit/cast ratio is $0.97 \%$ and the net present value is negative (Table 11). Such results would suggest that the society would not be better off with the project, only due to the increase in the social discount rate. In the case of the kindergarten complex, an additional increase in the discount rate ( $8 \%$ or higher) would further deteriorate the results of the cost-benefit analysis. 
Table 11. Results of economic analysis under different social discount rates for the kindergarten complex.

\begin{tabular}{ccc}
\hline Social Discount Rate & $\mathbf{5 \%}$ & $\mathbf{8 \%}$ \\
\hline Benefit/cost ratio & 1.45 & 0.97 \\
Economic net present value & EUR 0.87 million & EUR $-56,111$ \\
\hline
\end{tabular}

Source: Authors' calculations.

\section{Conclusions}

According to the Energy Efficiency Directive (2012/27/EU and 2018/2002), the annual rate of refurbishment should amount to $3 \%$ of the total surface area of buildings occupied by the central government. Decarbonization of the national building stocks by 2050 is required by the Directive on Energy Performance of Buildings (2010/31/EU and 2018/844). More renewable-based heating and cooling in buildings is called by the Directive 2018/2001 for the promotion of the use of energy from renewable sources. The paper presents results of option analyses and the CBA of investment projects in three public buildings with energy efficiency and non-energy efficiency costs and benefits in Serbia and Croatia.

- The results of a case study on a hospital building indicate a negative net present value, implying that the proposed investment is not financially viable. From the owners point of view, such a result negatively affects the attractiveness of the project. This is in line with previous findings that government support could significantly improve the financial viability of energy efficiency projects $[17,19]$.

- The case studies on an emergency health care center and a kindergarten complex suggest that energy efficiency benefits are not sufficient to justify the energy related costs. This does not mean that the project is not convenient for the society. Such a result requires the calculation of economic return to determine if the society would be better off with the project. Inclusion of not only EE costs and benefits, but also non-EE costs and benefits, provides the basis for the comprehensive assessment of the project's feasibility and its impact for the entire society. The non-energy benefits are project specific and consist of health benefits, education benefits and the avoided costs of child care.

- Following the inclusion of both EE and non-EE costs and benefits in CBA of emergency health care center and kindergarten complex projects, the economic net present value is positive and the benefit/cost ratio is greater than 1 in both cases. Such results suggest that the projects are economically viable. Co-benefits or multiple project benefits of various projects, which include the impact on GDP, employment, labor income, rental income and building sales price, are assessed in the literature [11,14,16-18]. Since such benefits are not applicable to these specific projects, the results of the CBA are not comparable to the results presented in the literature.

- In the case of the emergency health care center, the greatest benefit is associated with education as it would improve the quality of health care services. The O\&M cost savings follow in importance due to the expected energy savings. In the case of the kindergarten complex, a major benefit is the comfort benefit as a consequence of a higher indoor temperature. The improved air quality is expected to result in avoided cost of child care and avoided health care costs. The reduction of $\mathrm{CO}_{2}$ emissions and airborne pollutants would generate significant benefits as well.

- A factor that affects the conclusion of cost-benefit analysis is the choice of a discount rate. A sensitivity analysis was performed to present the CBA results with different social discount rates for the hospital building and the kindergarten complex. If the social discount rate would increase, the net present value would decrease as the costs come up-front and benefits come later. If a rate of $7 \%$ or higher is used, the benefit/cost ratio would be less than 1 and the net present value would be negative in both cases. Such results suggest that the conclusions of CBA would change and that projects would not be economically viable only due to the increase in the social discount rate from $5 \%$ to $7 \%$. 
The next step will be the development of an energy efficiency investment project prioritization tool. The aim of the tool is to identify projects of highest saving potential under a specific budget constraint and/or specific retrofit rate. This tool is valuable for public and any other building stock managing company as it allows the development of implementation plans for energy refurbishment of buildings, provided the building inventory is available. Indicators for investment size, energy and $\mathrm{CO}_{2}$ saving and investment efficiency are defined for different refurbishment scenarios and then evaluated by multicriteria analysis.

\subsection{Contribution}

This research establishes a framework for performing option analyses and cost-benefit analyses for investments in specific public buildings (hospital, emergency health care center, kindergarten complex) which include not only energy efficiency but also non-energy efficiency costs by using empirical data. It also empirically examines the feasibility of a range of options in order to assess the technical, economic and environmental convenience of a project. The proposed option analyses and cost-benefit analyses, as well as the methods for calculating energy and non-energy benefits, provide useful cases to conduct CBA of energy efficiency projects with non-energy costs and benefits of similar characteristics.

The results are derived from case studies in Serbia and Croatia under similar conditions including the building type, climate zone and building systems. Option analyses and CBA offer a better insight to investors for their decisions. To promote energy efficiency investments with non-energy costs and benefits, the policy makers will be better informed of the possible policy directions.

\subsection{Policy Implications}

The following policy implications are drawn from the case studies:

- The proposed investments are not financially viable. Therefore, government policy instruments such as government subsidies need to be in place as they could significantly improve the financial feasibility for the owner of the infrastructure and investors.

- The financial and economic analysis results satisfy the requirements of applying for EU grant financing. Given the EU objective of decarbonizing the national building stocks by 2050, securing EU funds for similar projects would be justified.

- The choice of social discount rate significantly affects the conclusions of the cost-benefit analyses. The discount rate should be set at the national level to reflect the country's social view of how future benefits and costs are to be valued against present ones.

- Establishing building inventory, investigating the saving potential and preparing high quality projects able to reach the savings in real use and the use of renewable energy is the way to achieve the decarbonization of the building stock. The key is the preparation of portfolio of projects, flexibly organized to be easily adapted to a range of priorities and available financing mechanisms.

Author Contributions: Conceptualization, M.Đ. and M.Z.; methodology, M.Đ. and M.Z.; validation, M.Đ. and M.Z.; formal analysis, M.Đ. and M.Z.; investigation, M.Đ. and M.Z.; resources, M.Đ. and M.Z.; data curation, M.Đ. and M.Z.; writing—original draft preparation, M.Đ. and M.Z.; writingreview and editing, M.Đ.; visualization, M.Đ. and M.Z.; supervision, M.Đ.; project administration, M.Đ. and M.Z.; funding acquisition, M.Z. All authors have read and agreed to the published version of the manuscript.

Funding: This research is being funded by "SmartCity.Energy \& Environment" project KK.01.2.2.03.0004 Competence centre for Smart Cities, implemented in Croatia.

Institutional Review Board Statement: Not applicable.

Informed Consent Statement: Not applicable.

Conflicts of Interest: The authors declare no conflict of interest. 


\section{References}

1. Filippidou, F.; Jimenez Navarro, J.P. Achieving the Cost-Effective Energy Transformation of Europe's Buildings; EUR 29906 EN; Publications Office of the European Union: Luxembourg, 2019; ISBN 978-92-76-12394-1. [CrossRef]

2. Directive (EU) 2018/2002 of the European Parliament and of the Council of 11 December 2018 amending Directive 2012/27/EU on energy efficiency. 2018. OJ L 328, 21.12.2018. Available online: https://eur-lex.europa.eu/legal-content/EN/TXT/?uri= uriserv\%3AOJ.L_.2018.328.01.0210.01.ENG (accessed on 22 May 2021).

3. Directive (EU) 2018/844 of the European Parliament and of the Council of 30 May 2018 amending Directive 2010/31/EU on the energy performance of buildings and Directive 2012/27/EU on energy efficiency 2018. OJ L 156, 19.6.2018. Available online: https: / / eur-lex.europa.eu/legal-content/EN/TXT/PDF/?uri=CELEX:32018L0844\&from=IT (accessed on 22 May 2021).

4. Directive (EU) 2018/2001 of the European Parliament and of the Council of 11 December 2018 on the promotion of the use of energy from renewable sources 2018. OJ L 328, 21.12.2018. Available online: https:/ / eur-lex.europa.eu/legal-content/EN/TXT/ PDF/?uri=CELEX:32018L2001\&from=fr (accessed on 22 May 2021).

5. European Parliament. Report on Maximising the Energy Efficiency Potential of the EU Building Stock; European Parliament: Brussels, Belgium, 2020. Available online: https:/ / www.europarl.europa.eu/doceo/document/A-9-2020-0134_EN.pdf (accessed on 20 March 2021).

6. Ministry of Construction, Physical Planning and State Assets of Croatia. Use of European Structural and Investment Funds, Operative Program Cohesion and Competitiveness; Ministry of Construction, Physical Planning and State Assets of Croatia: Zagreb, Croatia, 2014.

7. Ministry of Construction, Physical Planning and State Assets of Croatia. Energy Refurbishment Program od Multiresidential Buildings; Ministry of Construction, Physical Planning and State Assets of Croatia: Zagreb, Croatia. Available online: https:/ / mgipu.gov.hr/o-ministarstvu-15/djelokrug/energetska-ucinkovitost-u-zgradarstvu/energetska-obnova-zgrada-8321 / energetska-obnova-visestambenih-zgrada-8323/8323 (accessed on 14 February 2021).

8. Ministry of Construction, Physical Planning and State Assets of Croatia. Long-Term Strategy of Energy Refurbishment of National Building Stock Until 2050, 2020, Official Gazette of the Republic og Croatia No 140/2020. Available online: https:/ /mgipu. gov.hr/UserDocsImages / / dokumenti/EnergetskaUcinkovitost/ / Dugorocna-strategija-2050-sazetak_EN.docx (accessed on 14 February 2021).

9. Ryan, L.; Campbell, N. Spreading the Net: The Multiple Benefits of Energy Efficiency Improvements; IEA Energy Papers; OECD Publishing: Paris, France, 2012. [CrossRef]

10. Saldivia, M.; Kristjanpoller, W.; Olson, J.E. Energy consumption and GDP revisited: A new panel data approach with wavelet decomposition. Appl. Energy 2020, 272, 115207. [CrossRef]

11. Sooriyaarachchi, T.M.; Tsai, I.T.; El Khatib, S.; Farid, A.M.; Mezher, T. Job creation potentials and skill requirements in, PV, CSP, wind, water-to-energy and energy efficiency value chains. Renew. Sustain. Energy Rev. 2015, 52, 653-668. [CrossRef]

12. Dell'Anna, F. Green jobs and energy efficiency as strategies for economic growth and the reduction of environmental impacts. Energy Policy 2021, 149, 112031. [CrossRef]

13. Kerr, N.; Gouldson, A.; Barrett, J. The rationale for energy efficiency policy: Assessing the recognition of the multiple benefits of energy efficiency retrofit policy. Energy Policy 2017, 106, 212-221. [CrossRef]

14. Bleyl, J.W.; Bareit, M.; Casas, M.A.; Chatterjee, S.; Coolen, J.; Hulshoff, A.; Lohse, R.; Mitchell, S.; Robertson, M.; Ürge-Vorsatz, D. Office building deep energy retrofit: Life cycle cost benefit analyses using cash flow analysis and multiple benefits on project level. Energy Effic. 2019, 12, 261-279. [CrossRef]

15. Galatioto, A.; Ricciu, R.; Salem, T.; Kinab, E. Energy and economic analysis on retrofit actions for Italian public historic buildings. Energy 2019, 176, 58-66. [CrossRef]

16. Liu, Y.; Liu, T.; Ye, S.; Liu, Y. Cost-benefit analysis for Energy Efficiency Retrofit of existing buildings: A case study in China. J. Clean. Prod. 2018, 177, 493-506. [CrossRef]

17. Mikulić, D.; Bakarić, I.R.; Slijepčević, S. The economic impact of energy saving retrofits of residential and public buildings in Croatia. Energy Policy 2016, 96, 630-644. [CrossRef]

18. Novikova, A.; Szalay, Z.; Horváth, M.; Becker, J.; Simaku, G.; Csoknyai, T. Assessment of energy-saving potential, associated costs and co-benefits of public buildings in Albania. Energy Effic. 2020, 13, 1387-1407. [CrossRef]

19. Copenhagen Economics. Multiple Benefits of Investing in Energy Efficient Renovation of Buildings; CE: Copenhagen, Denmark, 2012.

20. Filippidou, F.; Nieboer, N.; Visscher, H. Energy efficiency measures implemented in the Dutch non-profit housing sector. Energy Build. 2016, 132, 107-116. [CrossRef]

21. Filippidou, F.; Nieboer, N.; Visscher, H. Are we moving fast enough? The energy renovation rate of the Dutch non-profit housing using the national energy labelling database. Energy Policy 2017, 109, 488-498. [CrossRef]

22. Rosenow, J.; Platt, R.; Demurtas, A. Fiscal impacts of energy efficiency programmes-The example of solid wall insulation investment in the UK. Energy Policy 2014, 74, 610-620. [CrossRef]

23. Sartori, D.; Catalano, G.; Genco, M.; Pancotti, C.; Sirtori, E.; Vignetti, S.; Del Bo, C. Guide to Cost-Benefit Analysis of Investment Projects. Economic Appraisal Tool for Cohesion Policy 2014-2020; European Commission: Brussels, Belgium, 2014.

24. Thollander, P.; Karlsson, M.; Rohdin, P.; Wollin, J. Introduction to Industrial Energy Efficiency: Energy Auditing, Energy Management, and Policy Issues; Academic press: Cambridge, MA, USA, 2020. 
25. Korytárová, K.; Knapko, I.; Šoltésová, K. Energy savings potential for space heating in public buildings in Slovakia. In Proceedings of the European Council for an Energy Efficient Economy Summer Study 2017, Hyères, France, 29 May-3 June 2017; pp. 1393-1399.

26. Sandberg, N.H.; Sartori, I.; Heidrich, O.; Dawson, R.; Dascalaki, E.; Dimitriou, S.; Vimm-r, T.; Filippidou, F.; Stegnar, G.; Šijanec Zavrl, M.; et al. Dynamic building stock modelling: Application to 11 European countries to support the energy efficiency and retrofit ambitions of the EU. Energy Build. 2016, 132, 26-38. [CrossRef]

27. Pearce, D.W. Cost-Benefit Analysis; Macmillan International Higher Education: London, UK, 2016.

28. Stiglitz, J.E.; Rosengard, J.K. Economics of the Public Sector: Fourth International Student Edition; WW Norton \& Company: New York, NY, USA, 2015.

29. Sáez, C.A.; Requena, J.C. Reconciling sustainability and discounting in Cost-Benefit Analysis: A methodological proposal. Ecol. Econ. 2007, 60, 712-725. [CrossRef]

30. László, S.; Mezősi, A.; Pató, Z. South East Europe Electricitiy Roadmap: Country Report: Serbia; SEERMAP—South East European Roadmap Project ISBN 978-615-80813-5-1. 2017. Available online: https:/ / rekk.hu/analysis-details/238/south-east-europeelectricity-roadmap---seermap (accessed on 15 February 2021).

31. Ten Year Network Development Plan; ENTSO: Brussels, Belgium, 2018.

32. Climate Change and Major Projects; European Commission, Directorate-General for Climate Action: Brussels, Belgium, 2016.

33. NEEDS (New Energy Externalities Developments for Sustainability). External Costs from Emerging Electricity Generation Technologies, Project co-funded by the European Commission. 2009. Available online: https://cordis.europa.eu/project/id/5026 87 (accessed on 14 February 2021).

34. Viscusi, W.K.; Masterman, C. Income Elasticities and Global Values of a Statistical Life. J. Benefit-Cost Anal. 2017, 8, 1-25. [CrossRef]

35. American Society of Heating, Refrigerating and Air-Conditioning Engineers. ASHRAE Handbook-Fundamentals. 2017. Available online: https:/ / www.ashrae.org/technical-resources/ashrae-handbook (accessed on 15 March 2021). 